\title{
Of Kate Moss \& Marilyn Monroe: Body Dissatisfaction and its Relation to Media Consumption, Body Mass Index and Self-Esteem in Malaysian College Women
}

\author{
Ulaș Bașar Gezgin ${ }^{1}$ \\ Valerie Clarissa Ann Dev²
}

\begin{abstract}
Can individual differences in body dissatisfaction be predicted? What would those predictors be? This study investigated whether media consumption, self-esteem, and Body Mass Index (BMI) were predictors of body dissatisfaction. The sample constituted of 149 female college students from 4 universities in Malaysia. To answer the question of the study, participants' height and weight were collected along with their answers to Media Consumption Scale, the Rosenberg's Self-Esteem Scale, and Body Esteem for Adolescents and Adults. A few analyses such as the independent samples t-test, One-way ANOVA, Pearson's Correlation and Multiple Regression were conducted on the data. Results of the study indicated that self-esteem and BMI could predict body dissatisfaction in college women. However, the study indicated that media consumption did not. The findings were discussed with regard to relevant theories such as the self-discrepancy theory, social comparison theory, and objectification theory.
\end{abstract}

Keywords: Psychology of Communication, Media Psychology, Body Satisfaction, Body Mass Index and SelfEsteem.

\section{Kate Moss ve Marilyn Monroe Üstüne: Malezyalı Kolej Kadınlarında Bedenle İlgili Hoșnutsuzluğun Medya Tüketimi, Vücut Kitle İndeksi ve Benlik Saygısı Ile ilișkisi}

Öz

Bedenle ilgili hoşnutsuzluklardaki bireysel farklar tahmin edilebilir mi? Bu tahmin edici değişkenler neler olabilir? Bu çalışma, medya tüketiminin, benlik saygısının ve Vücut Kitle İndeksi'nin bedenle ilgili hoşnutsuzlukları tahmin edici değişkenler olup olmadığını inceledi. Örneklem, Malezya'daki 4 üniversitedeki 149 kadın kolej öğrencisinden oluştu. Çalışmanın ana sorusunu yanıtlayabilmek için, Medya Tüketim Ölçeği'ne, Rosenberg Benlik Saygısı Ölçeği'ne, ve Ergenler ve Yetişkinler için Beden Saygısı Ölçeği'ne verilen yanıtlar yanında, katııımcıların boyu ve ağırığı hakkında bilgiler toplandı. Veri üstünde, bağımsız örneklemli t testi, tek yönlü ANOVA, Pearson korelasyonu ve çoklu regresyon gibi çözümlemeler yapıldı. Çalışmanın sonuçları, benlik saygısı ile Vücut Kitle İndeksi'nin bedenle ilgili hoşnutsuzlukları tahmin edebildiğini gösterdi. Ancak, medya tüketiminin bedenle ilgili hoşnutsuzlukları tahmin edici nitelikte olmadığını da gösterdi. Bulgular, benlik uyuşmazlığı kuramı, toplumsal karşılaştırma kuramı ve nesneleştirme kuramı gibi ilgili kuramlarla bağlantılı olarak tartışıldı.

Anahtar Kelimeler: İletişim Psikolojisi, Medya Psikolojisi, Bedenle llgili Hoşnutluk, Vücut Kitle İndeksi ve Benlik Saygısı.

1 Doç. Dr. British University, Vietnam.

2 Bağımsız Araştırmacı, Malezya. 


\section{Introduction}

A study done by Dr. Hera Lukman of the International Medical College, suggests that $72 \%$ of college women are not satisfied with their bodies (The Star, 2007). A distorted body image r dissatisfaction of one's body has been linked to numerous factors such as low self esteem, development of eating disorders, excessive exercise, and dieting (Dohnt and Tiggemann, 2006: 929; Groesz et al., 2002: 1; Hobza et al., 2007: 161). Empirical evidence shows that cases of body dissatisfaction has markedly increased during the same time span that media images of women's bodies have become increasingly thinner (Vartanian et al., 2001: 711) with about 90\% of women depicted in the media being approximately $15 \%$ below the normal weight range (Tucci and Peters, 2008: 521). Numerous studies have found the media to be part of the cause of body dissatisfaction (Ogden and Mundray, 1996: 171; Swami et al., 2011: 57). Even the American Psychological Association concluded that thin media images contribute to body dissatisfaction in women (Ferguson et al., 2011: 12). Posavac and Posavac (2002: 153) on the other hand, reported that not all women report body dissatisfaction as a result of media exposure. Thus, it is not explicitly clear if media exposure is directly related to body dissatisfaction, or if there are other factors such as self-esteem and Body Mass Index (BMI), that synergizes the relationship between the media and body satisfaction.

Stice and Shaw (as cited by Swami et al, 2011: 57) defined body dissatisfaction as the "negative self-evaluations of one's own body". More commonly though, body dissatisfaction is defined as a discrepancy between perceived body size and the desired body size (Ogden and Mundray, 1996: 171), due to an awareness and internalization of a thin body ideal and a subsequent perception of pressure to be thin (Calado et al., 2011: 394). In the current study, body dissatisfaction will be measured using the Body Esteem Scale for Adolescents and Adults (Mendelson et al., 2001: 90). This instrument has been used in other studies that focused on body dissatisfaction, selfesteem, eating disorders, and weight status among other things. Self-esteem has been defined as a person's overall evaluation of their self (Barlett et al., 2008: 182) and is measured through Rosenberg's Self-Esteem Scale. Groesz et al. (2002: 1) include visual forms of media such as magazines and television in defining media. For the purposes of this study, television shows, music videos, and magazines make up the definition of media and media consumption is measured using the Media Consumption Scale (Stice and Shaw, 1994). Finally, the National Heart, Lung and Blood Institute (NHLBI) defines BMI as amount of fat in a body based on an individual's height and weight, and is measured using participants' height (in $\mathrm{cm}$ ) and weight (in kg).

The social comparison theory (Festinger, 1954: 117) claims that individuals acquire information and learn about themselves comparing themselves to other people. They do this, he says, because people have a desire to accurately evaluate their attitudes and beliefs. The comparison is usually done with people who are perceived to be better than the self (Hobza et al., 2007: 161). Hobza et al. (2007) found that this social comparison may be the most important information a person considers in certain situations even if people have objective information at hand. With regard to thin media images, people may know, objectively, that media images are distorted or have information on healthy weight values, and still compare themselves to the unrealistic images portrayed in the media, thereby start feeling dissatisfied with their bodies. In fact, research by Froddy and Crundall; Wood and Wilson (as cited by Hobza et al., 2007: 161) supports this theory.

The self-discrepancy theory proposed by Higgins (1987:319) explains that discrepancies between the actual self and the ideal self creates dissatisfaction. Therefore, problems arise when women compare themselves to the ultra-thin images presented in the media because these images could 
cause a large discrepancy to occur between their actual bodies and the ideal body (Posavac and Posavac, 2002: 153). This perceived discrepancy then leads to a heightened disturbance in body image (Posavac and Posavac, 2002: 153), self-esteem issues and negative affect (Cohen, 2006: 57).

Evolutionary psychology provides two theories that have helped psychologists understand human behavior - natural selection (better known as survival of the fittest) and sexual selection (Buss, 2008: 144). Evolutionary psychology claims that human beings conduct themselves in a predetermined pattern because it is innately inherent in us to do so. For example, Marcus (2008: 27) argues before the advent of technology and cosmetic surgery, smooth skin indicated the fertility of a potential partner. Since this trait was helpful for the survival of the species, our ancestors were partial to smooth skin, and though evolution it has become imprinted in our DNA to also favor this trait (Marcus, 2008: 27). Further, in the time of our ancestors the way a woman looked (i.e.: her body shape) represented her future potential reproductive capabilities; there was, in the time of our ancestors, a preference for a curvaceous figure. Following this line of thought, it could be argued that media portrayals of slender images are not detrimental to women's body image but instead it is the physical manifestation of a biological preference. In essence then, the media is simply commercializing biology, and thus is not the actual reason behind body dissatisfaction. This argument is plausible since each generation is born taller and larger than the last. However, to which extent media portrayal matches the thin hourglass figure preferred by our ancestors remains to be contested.

Finally, Fredrickson's (1997: 173) theory of objectification explains the consequences of media images on a woman's mental well being. In the journal Fredrickson (1997: 173) argues that women are socialized into internalizing an observer's view of their bodies. Due to this, women then become ashamed and anxious, and these accumulated experiences of shame and guilt lead to "mental health risks" (Fredrickson, 1997: 173). What this means is that women acculturated to objectify and evaluate themselves based on their appearance alone (Morry and Staska, 2001: 269). Groesz, Levine and Murnen (2002: 2) reasons that this self-objectification creates an "appearance consciousness" in the individual. It is this consciousness then that increases the discrepancy a woman might have of her actual and ideal body. Fredrickson (1997: 173) makes an important point which is social standard can only affect women who have internalized the social standards. The theory goes on to argue that given prolonged exposure to such standards and objectifications, people may be coaxed into internalizing that standard and participate in selfobjectification.

Past studies on the linkage between body dissatisfaction, BMI, self esteem and media consumption have yielded mixed results. For example, Schooler and Trinh (2011: 34) conducted a longitudinal research that studied television show viewing and its predictive effect on body satisfaction. Schooler and Trinh (2011: 34) concluded that longer hours spent watching television significantly predicted lower body satisfaction among adolescent girls. Miller and Halberstadt (2005: 189) also found that only women's consumption of media predicted body dissatisfaction even though there were no significant differences between men and women's media consumption. The study further indicated that consumption of music videos had a large predictive factor on body dissatisfaction in women whereby the more hours a woman spent watching music videos, the lower her body satisfaction. Awareness and internalization of the social norm was also found to be a predictor of body dissatisfaction in women but not in men (Miller and Halberstadt, 2005: 189).

Kim and Lennon's (2007: 3) results indicating that exposure to beauty as well as fashion 
magazines predicted an overall dissatisfaction with appearance and tendencies for eating disorder. However, they found that there was no significant relationship between television exposure and dissatisfaction with one's body. They also ascertained that the risk of developing an eating disorder was associated to low self esteem and body dissatisfaction. In addition, Sheldon (2010: 277) established that there was no significance between media use and body esteem in students. However, the results of the study indicated that higher levels of peer and family pressure predicted that women would compare themselves to media models which would then result in a negative body image.

Aubrey (2006: 159) conducted a 2 year study on the exposure to sexually objectifying media and its relation to body shame and appearance anxiety. Controlling for these factors as well as global self esteem in Time 1, Aubrey (2006: 165) reported that an increase in sexually objectifying media predicted higher body shame and appearance anxiety, especially in women who had lower global self esteem. In a study on men's media consumption of magazines, Hatoum and Belle (2004: 397) established that low self esteem in men was linked to their concerns over weight. Interestingly, the study also found that an increase in male directed magazine consumption lead men to value thinness in women. Thogersen-Ntoumani et al. (2011: 289), conducted an experiment based on the self-objectification theory which tested how self-objectification, self-esteem and evaluation of appearance predicted mood states and body satisfaction in university students. Results indicated that low self-esteem predicted depression, anger and low body satisfaction while high self-esteem was associated to high body satisfaction and positive mood states.

Some studies also suggested a relationship between BMI and body dissatisfaction. For instance, Laus et al. (2011: 315) carried out a study that evaluated body dissatisfaction and its relationship to BMI and physical activity in adolescents. The study concluded that girls had a higher body dissatisfaction than boys, and that even girls with normal body weight desired to be thinner. The study concluded that in girls, body satisfaction was related to BMI. A study on African American College women's body image done by Jameca and Neville (2000: 236) indicated that African self-consciousness, skin color satisfaction and BMI all predicted body satisfaction. In particular, greater BMI scores were related to a lower overall satisfaction in appearance. On the other hand, Weaver and Byers (2006: 333) found that exercise and BMI did not predict healthy body image; there was no significant relationship between body image and BMI.

Though there has been an increase in studies on the media and body dissatisfaction, the link between body dissatisfaction and self-esteem, and body dissatisfaction and BMI has remained relatively unexplored with limited literature discussing the subjects. Moreover, the studies that do talk about the factors mentioned, are focused primarily on a Western sample and there has not been that many empirical data on the topic amongst an Asian sample. Also, the relationship between BMI and body dissatisfaction explored in this research can supplement the constricted literature with this focus. To that end, the study has 3 main objectives; (1) To determine if BMI is a predictor of body dissatisfaction in Malaysian college women, (2) To determine if self-esteem is a predictor of body dissatisfaction in Malaysian college women, and (3) To determine if media consumption is a predictor of body dissatisfaction in Malaysian college women. Following that, it is hypothesized that BMI is a predictor of body dissatisfaction, in that, as BMI increased, body dissatisfaction increases as well. Secondly, it is hypothesized that body dissatisfaction can be predicted by self-esteem, where lower levels of self-esteem would be linked to higher levels of body dissatisfaction. Finally, it is predicted that media consumption predicts body dissatisfaction, whereby higher levels of media consumption leads to higher levels of body dissatisfaction. 


\section{Participants}

\section{Method}

A total of 166 female participants were recruited from SEGi University College (Kota Damansara), KDU College (Kota Damansara), INTI College (Subang Jaya), and Methodist College Kuala Lumpur (Brickfields). However, 17 participants were not included in the sample because they did not complete sections of the questionnaire like the Rosenberg Self-Esteem Scale or were not part of the target population. Thus, a total of 149 participants made up the sample of the study. Of the total, $28.86 \%$ of the participants were from INTI, $26.85 \%$ were from SEGi, $25.5 \%$ were from KDU and $18.79 \%$ were from Methodist College (MCKL). SEGi University College has an emphasis on health sciences, although the institution does offer various other programs. Meanwhile KDU College has a focus in Culinary Arts and Hospitality Management. INTI College is primarily a business school while MCKL caters mostly to pre-graduate studies. The participants' ages were between 17 and 23 years old; mode, $19(\mathrm{M}=19.46, \mathrm{SD}=1.27)$. A non probability method, convenient sampling, was used to choose participants in the college setting. Parallel to Zikmund's (1997) argument, this sampling method was the easiest and most economical given the researcher's limited resources. $63.09 \%$ of the participants were Chinese, $19.46 \%$ were Indian, $12.75 \%$ were Malay, and $4.7 \%$ made up other races.

\section{Materials}

A few measures were used in this study and they include BMI, the Body Esteem Scale for Adolescents and Adults, the Rosenberg Self-Esteem Scale and the Media Consumption Scale. The demographics questionnaire was used to gather the basic information of participants such as their age, college, course, weight, height, religion, ethnicity, and monthly household income.

Body Mass Index. Body Mass Index is a fatness indicator of an individual's body and it is based on medical criteria which can then be used to screen for categories of weight (CDC, 2011). BMI was assed using the participants' height and weight. The formula for calculating BMI is weight $(\mathrm{kg})$ divided by height $(\mathrm{m})$ squared or weight $(\mathrm{kg}) /$ [height $(\mathrm{m})]^{2}$. Height will be converted from centimeters to meters by dividing it by 100 . BMl has 4 main categories and it ranges from underweight to overweight (NHLBI, 2012).

Body Esteem Scale for Adolescence and Adults. The Body Esteem Scale for Adolescence and Adults (Mendelson et al, 2001: 90), is a 21 item inventory with a 5-point Likert scale ranging from 1 (never) to 5 (always). The test measures 3 factors of body esteem which are appearance (e.g.: "I think my appearance would help me get a job"), attribution (e.g.: "Other people consider me good looking"), and weight (e.g.: "I am satisfied with my weight"). Questions that were related to appearance were $1,6,7,9,10,12,14,16,19$, and 21 while questions $3,4,8,15,17$, and 20 were related to weight. Finally, questions 2, 5, 11, 13 and 18 measured attribution. In this scale, questions 4, 7, 9, 10,12, 16, 17 and 19 were reversed. The scale had a high internal consistency as well as a high test-retest reliability ( $\alpha=0.81-0.94)$; (Allison and Baskin, 2009: 25; Mendelson et al., 2001: 90).

Rosenberg Self-Esteem Scale. Self-Esteem was measured using the Rosenberg Self-Esteem Scale (Rosenberg, 1965). The measure consists of 10 items with a 4-point Likert scale ranging from SD (strongly disagree) to SA (strongly agree). This scale has been used in numerous studies (such as de Man and Gutiérrez, 2002: 235; Gudjonsson and Sigurdsson, 2003: 117; Liu and Iwamato, 2006: 153; Lopez, 2008: 102), and contains both positive and negative statements. A sample question in the inventory would be "On the whole, I am satisfied with myself". The reversed questions on this scale were 2, 5, 6, 8 and 9. Greenberger et al. (2003: 1241); Martin- 
Albo et al (2007: 458) found that the test was suitable for students in higher education and that it had a test-retest validity of $a=0.84$.

Media Consumption Scale. The Media Consumption Scale (Stice and Shaw, 1994), served as a self-report inventory on an individual's exposure to, and consumption of the media in the form of television and magazines. There were 8 questions related to the consumption of television (e.g.: "How many hours of Comedy shows such as Friends, Two and a Half Men and How I Met Your Mother do you watch in an average week?") and 5 questions related to Magazine (e.g.: "How many hours do you spend reading Entertainment or Arts magazines such as Entertainment Weekly or People in an average week?"). The current study used a slightly modified scale whereby television shows and magazines reflected those that were currently popular in Malaysia. Reliability for this scale using the test-retest method was $=.76$ (Stice and Shaw, 1994).

\section{Procedures}

Participants of the current study were recruited from the libraries of their respective colleges. Respondents were told of the purpose of the study, and then asked if they were willing to take part in the study. Next, they were given a questionnaire and asked to complete the demographic information, the Body Esteem Scale for Adolescents and Adults, the Rosenberg Self-Esteem Scale and the Media Consumption Scale. The media consumption scale was put last so that it would not affect the results of the other scales.

\section{Results}

\section{General Statistics and Tests}

In this study, $63.09 \%$ of the respondents were Chinese; therefore, a comparison between ethnicities could not be conducted. Also, $40.3 \%$ of the participants were Buddhists, $25.5 \%$ were Christians, $15.4 \%$ were Muslims, $13.4 \%$ were Hindus and $5.4 \%$ fell into other religions. Thus, a comparison between religions could not be carried out. However, a comparison between Buddhists and Non-Buddhists was made. Results indicated that there was no significant difference between Buddhists and Non-Buddhists on body dissatisfaction, $t(147)=3.98, p>0.5$, self-esteem, $t(147)$ $=2.98, p>0.5$, and $\mathrm{BMI}, \mathrm{t}(147)=-.034, \mathrm{p}>0.5$. However, there was a significant difference between Buddhists $(M=29.98, S D=22.70)$ and Non-Buddhists $(M=42.20, S D=39.39)$ on media consumption, $\mathrm{t}(147)=2.397, \mathrm{p}<.05$. There was no significant difference between colleges and $\mathrm{BMI}, \mathrm{F}(3,145)=1.877$, body dissatisfaction, $F(3,145)=3.651$, self esteem, $F(3,145)=$ 2.897, or media consumption, $F(3,145)=3.278$.

An independent samples t-test was carried out to determine differences between different income groups. Based on the cumulative percentage, the low income group included an income of RM 5000 and below while the high income group was in income of above RM 5001. The results indicated that there was no significant difference between the low income group ( $M=65.84$, SD $=13.44)$ and high income group $(M=69.33, S D=13.11)$ on body dissatisfaction, $t(135)=-1.59 p$ $>$.05. Further, no significant difference was found between income levels and self-esteem, $t(147)$ $=-1.271, p>.05$, or media consumption, $t(147)=.984, p>.05$. Finally, no significant difference was found between the low income group $(M=21.18, S D=3.53)$ and high income $(M=20.53$, $\mathrm{SD}=2.94)$ group on $\mathrm{BMI}, \mathrm{t}(144)=1.22 \mathrm{p}>.05$.

A reliability test was carried out on the Body Esteem Scale for Adolescences and Adults (BESAA). The BESSA was found to be highly reliable $(21$ items; $\alpha=.88)$. There was a high reliability for the first factor and the third factor; (16 items; $a=.88$ ) and ( 2 items $a=.75$ ) respectively. The 
second factor was moderately reliable ( 3 items; $\alpha=.57$ ). A confirmatory factor analysis (Principal Component Analysis) was executed on the 3 factors of the BESAA. It was found that the results were not consistent with the results of a study done by Mendelson et al (2001: 90) where 10 items loaded high on factor 1, 6 items loaded high on factor 2, and 5 items loaded high on factor 3. A reliability test conducted on the Rosenberg's Self Esteem Scale revealed that it was highly reliable (10 items; $a=.76$ ).

\section{Body Mass Index}

There are four major BMI classifications. Underweight is classified as a BMI of less than 18.5. According to the NHLBI, the normal weight range is between $18.5-24.99$ while overweight ranges from $25-29.99$ and a BMI of 30 and above is classified as obese. The participants' BMI ranged from 15.21 to 31.89 . The mean $\mathrm{BMI}$ for this study was 20.91 which is the normal weight range according to the medical classification as provided by the NHLBI (2012).

\section{Predictors of Body Dissatisfaction and Relationships Between Variables}

Multiple regression analysis was used to examine whether BMI, media consumption and self esteem significantly predicted body dissatisfaction. The Adjusted $R^{2}$ for this model was .31 and the model significantly predicted differences in body satisfaction, $F(3,145)=23.38, p<.001$. Self esteem $(\beta=.544, p<.001)$ and BMI $(\beta=-.202, p<.001)$ were found to be significant predictors of body dissatisfaction. However, results indicated that media consumption did not predict body dissatisfaction; hence, there is no support for hypothesis 1 .

Pearson's Correlation test was used to find the relationship between body dissatisfaction and the 3 aforementioned variables; BMI, self-esteem and media consumption. Results of the Pearson's Correlation analysis indicated that there was a weak negative correlation between BMI and body dissatisfaction, $r(149)=-.173, p<0.05$. Results of the test also showed that there was a significant difference between self-esteem and body satisfaction. Body satisfaction and self-esteem showed a strong positive correlation, $r(149)=.533, p<0.01$. However, no significant correlation between media consumption and body dissatisfaction was found.

\section{Discussion}

Converging with Frederick et al. (2007: 317); Jameca and Neville (2000: 236) and diverging with Weaver and Byers (2006: 333), this study found BMI to be a significant predictor of body dissatisfaction. Specifically, a higher BMI is associated to higher levels of body dissatisfaction which shows support for the first hypothesis of the study. In 2011, The Star reported that $43 \%$ of Malaysian adults were either obese or overweight; the number was equivalent to 2 out of 5 Malaysian adults being over the normal BMI range (Tan, 2011). This is an interesting fact since almost half of the adult population, which includes college students, fall on the heavier side of the BMI spectrum. Given this statistic, it is easy to see the link between body dissatisfaction and BMI. Because students are, on average, heavier than they should be for their height, they are not satisfied with their bodies.

With the results of this study, it can be inferred that if a thin person or a person with a normal BMI views thin images, it should not negatively impact their body image, and those that do may have issues with eating disorders or could be at risk to developing eating disorders. This link between $\mathrm{BMI}$ and body dissatisfaction can also be explain through the theory of evolutionary psychology. As argued earlier, our predecessors found hourglass figures and slimmer forms to be more attractive as well as having more potential to be fertile. Thus, it was in the best interest of human 
survival for women to be slighter, because of this, human beings have been preprogrammed to desire a slimmer form. Due to this programming, it can be argued that women feel dissatisfied with their bodies that do not fit the standards of perceived fertility as in the time of our ancestors.

Also concurrent with past studies (such as Dohnt and Tiggemann, 2006: 929; Groesz et al., 2002: 1; Hatoum and Belle, 2004: 397) is the finding of the current study that self-esteem predicts body dissatisfaction in college women. This finding supports the second hypothesis which was lower self-esteem would predict higher levels of body dissatisfaction. However, this can very well be bi-directional. Of importance is that self-esteem has been measured as a global construct, so it is difficult to truly determine if people feel dissatisfied with their bodies because they have low self-esteem or if their low self-esteem is the cause for their dissatisfaction. Many past studies have a similar problem whereby a stable, global measure of self-esteem is pitted against a specific measure of body dissatisfaction. An example of this is a study by Furnham et al. (2002) on adolescents which reported that girls' self-esteem was related to body dissatisfaction and that self-esteem was shaped by numerous factors such as influences of peers and the individual's family.

Using Higgins' (1987: 319) self-discrepancy theory, we can see how self-esteem might be added to the situation to distort body image leaving the individual feeling dissatisfied with their bodies. The essence of Higgins' argument is that discrepancies between a person's actual self (which is their self concept) and the ideal-self, is associated to negative emotions such as dissatisfaction. If self-esteem is a person's overall evaluation of their self (Barlett et al., 2008: 282), then it goes reason that a low self-esteem would cause a person to evaluate themselves negatively compared to some set standard (whether personal or set by society). So, a person with low self-esteem may perceive that her body is less attractive or is heavier than it actually is compared to standards in the media or standards that she has created for herself. This then causes a discrepancy between self and ideal which leads to the dissatisfaction with her body.

Finally, the results of this study indicate that the third hypothesis is not supported, and this is convergent with the findings of Kim and Lennon (2007: 3); Sheldon (2010:277) who concluded that media consumption does not bare any significance to body dissatisfaction. However, this result is in contrast with a majority of past studies such as Miller and Halberstadt (2005: 189); Schooler and Trinh (2011: 34) to name a few. Parroting the same line of reasoning used by evolutionary psychologists, it may seem that media does not play an important role in body dissatisfaction among college women because the media simply capitalizes on our innate drive to reproduce and survive which requires that women look a certain way. A better argument though is rooted in the objectification theory proposed by Fredrickson (1998: 173). Here, it is said that women are socialized (mainly by the media) into objectifying themselves; regarding themselves solely on the basis of their appearances. However, for this self-objectification to take place there must be an internalization of societal standards (Morray and Staska, 2001). In this case, it may be that people have become less affected and concerned with traditional media such as television and magazines, and are more affected by the Internet. Another possibility could be that the women in our study also watch reality television or news bulletins which feature women in many forms. In fact, the daily news features overweight, even obese female government officials which may lead women to believe that success and so on, does not necessarily correlate with having a slender figure. Also, the researcher found that there were some language barriers while conducting this study that could account for the non-significant results. For example, some participants may have taken the term television shows literally and only accounted for hours they spent watching television and not television shows on their laptops. The cumulation of these reasons could 
then account for why media consumption does not seem to have a significant influence on body dissatisfaction.

\section{Limitations}

The first limitation of the study is that it is only representative of female college population as a sample was taken from that pool. As such, the results may only be generalized to the female college students' population in Malaysia. Another limitation of this study is that it relied on participants' self-reported degree of dissatisfaction with their bodies. As Schwarz (1999: 339) said, self-report measures are susceptible to inaccurate data, particularly over- or underrating by participants. Therefore, it is probable that some of the participants may not have accepted the level of dissatisfaction they have with their bodies or may have even amplified levels of satisfaction with their bodies. A third limitation is that only 2 forms of media was examined, namely television and magazines. It is possible that examining more forms of media such as the internet, radio and newspapers, may provide better results indicating that media consumption can be a predictor of body dissatisfaction. Finally, the use of BMI was another limitation of this study. This limitation is two-fold. First, as BMI was calculated from participants' self-reported height and weight, it is possible that the data given was inaccurate or outdated. Secondly, BMI may not be the best method of assessing everyone. For example, some short people with a lot of muscle mass may be categorized as overweight according to the BMI scales.

\section{Future Research}

Based on the findings of the current study, there may be several directions for future research to take. First, since self-esteem is a stable characteristic, it may be interesting to conduct a longitudinal study to see if self-esteem is a consistent predictor of body dissatisfaction. The study could also be a comparison between young women and middle aged women or women that are older than that. Another suggestion for future research is more variables, such as psychological hardiness, internalization of societal standards, family influence, peer influence, childhood exposure to thin images (e.g.: Barbie dolls and cartoons) and so on, can be investigated to get a core complete picture of body dissatisfaction. Also, it is suggested that future studies collect BMI data based on the actual measurement of height and weight of the participants for more accurate results. It is also suggested that a different sampling method be used to recruit participants so that an equal number of participants from each race category can be collected for comparison. Finally, future researchers may be interested to explore the relationship between social media and body dissatisfaction.

\section{Conclusion}

It is becoming more apparent that in today's world issues of body dissatisfaction is becoming common place and many past studies have accredited this to the media. Although, this study did not find a relationship between the media and body dissatisfaction, numerous other studies have found that media contributes to low self-esteem which influences body dissatisfaction. Clearly, more research needs to be done on this area, especially concerning the relationships between media, self-esteem and body dissatisfaction. Once a full picture of this issue can be made, proper procedures and strategies to shield the young people from the detrimental effects of this problem can be made. Presently, this research shows that body dissatisfaction is a self-esteem and body mass index problem. This means that parents, teachers and school boards can take an active role in combating this issue. This also means that parents and teachers have a responsibility to foster self-esteem and acceptance of the self in children from a young age, which could then reduce body dissatisfaction problems. 


\section{References}

Allison, David B. and Baskin, Monica L. (2009). Handbook of Assessment Methods For Eating Behaviors And Weight-Related Problems: Measures, Theory, and Research. Thousand Oaks, CA: Sage.

Aubrey, Jennifer Stevens (2006). "Exposure to sexually objectifying media and body self-perceptions among college women: An examination of the selective exposure hypothesis and the role of moderating variables", Sex Roles. Vol.55: 159-172.

Barlett, Christopher P., Vowels, Christopher L. and Saucier, Donald A. (2008). "Meta analysis of the effects of media on men's body-image concerns", Journal of Social and Clinical Psychology. Vol.27: 279-310.

Buss, David M. (2009). "The great struggles of life: Darwin and the emergence of evolutionary psychology," American Psychologist. Vol.64: 140-148.

Calado, Maria, Lameiras, Maria, Sepulveda, Ana R., Rodriguez, Yolanda and Carrera, Maria V. (2011). "The association between exposure to mass media and body dissatisfaction among Spanish adolescents”, Women's Health Issues. Vol.21: 390-399.

Cohen, Sara B. (2006). "Media exposure and its subsequent effects on body dissatisfaction, disordered eating, and drive for thinness: A review of the current research", Mind Matters: The Wesleyan Journal of Psychology. Vol.1: 57-71.

De Man, A. F. and Gutiérrez, B. I. (2002). "The relationship between level of self-esteem and suicidal ideation with stability of self-esteem as moderator," Canadian Journal of Behavioral Science. Vol.34: 235-238.

Dohnt, Hayley and Tiggemann, Marika (2006). "The contribution of peer and media influences to the development of body satisfaction and self-esteem in young girls: A prospective study”, Developmental Psychology. Vol.42: 929-936.

Ferguson, Christopher J., Winegard, Benjamin, and Winegard, Bo M. (2011). "Who is the fairest one of all? How evolution guides peer and media influences on female body dissatisfaction", Review of General Psychology. Vol.15: 11-28.

Festinger, Leon (1954). "A theory of social comparison processes", Human Relations. Vol.7: 117-140.

Frederick, David A., Forbes, Gordon B., Grigorian, Kristina E., and Jarcho, Johanna M. (2007). "The UCLA body project I: Gender and ethnic differences in self-objectification and body satisfaction among 2,206 undergraduates", Sex Roles. Vol.57: 317-327.

Fredrickson, Barbara L., and Roberts, Tommi-Ann (1997). "Objectification theory: Towards understanding women's lived experiences and mental health risks", Psychology of Women Quarterly. Vol.21: 173-206.

Greenberger, Ellen, Chen, Chuansheng, Dmitrieva, Julia and Farruggia, Susan P. (2003). "Item-wording and dimensionality of the Rosenberg self-esteem scale: Do they matter?" Personality and Individual Differences. Vol.35: 1241-1254.

Groesz, Lisa M., Levine, Michael P. and Murnen, Sarah K. (2002). "The effect of experimental presentation of thin media images on body satisfaction: A meta-analytic review”, International Journal of Eating Disorders. Vol.31: 1-16. 
Gudjonsson, Gisli H. and Sigurdsson, Jon Fridrik (2003). "The relationship of compliance with coping strategies and self-esteem", European Journal of Psychological Assessment. Vol.19: 117-123.

Hatoum, Ida Jodette and Belle, Deborah (2004). "Mags and abs: Media consumption and bodily concerns in men", Sex Roles. Vol.51: 397-407.

Higgins, E. Tory (1987). "Self-discrepancy: A theory relating self and affect", Psychological Review. Vol.94: 319-340.

Hobza, Cody L., Walker, Karen E., Yakushko, Oksana and Peugh, James L. (2007). "What about men? Social comparison and the effects of media images on body and self-esteem", Psychology of Men and Masculinity. Vol.8: 161-172.

Jameca, Woody Falconer and Neville, Helen A. (2000). "African American college women's body image: An examination of body mass, African self-consciousness and skin color satisfaction", Psychology of Women Quarterly. Vol.24: 236-243.

Kim, Jung-Hwan and Lennon, Sharron J. (2007). "Mass media, self-esteem, body image, and eating disorder tendencies", Clothing and Textiles Research Journal. Vol.25: 3-23.

Laus, Maria F., Braga Costa, Telma M. and Almeida, Sebastiao S. (2011). "Body image dissatisfaction and its relationship with physical activity and body mass index in Brazilian adolescents", Jornal Brasileiro de Psiquiatria. Vol.60: 315-320.

Liu, William Ming and Iwamoto, Derek Kenji (2006). "Asian American men's gender conflict: The role of Asian values, self-esteem, and psychological distress”, Psychology of Men and Masculinity. Vol.7: 153-164.

Lopez, Irene (2008). "“But you don't look Puerto Rican”: The moderating effect of ethnic identity on the relation between skin color and self-esteem among Puerto Rican women", Cultural Diversity and Ethnic Minority Psychology. Vol.14: 102-108.

Marcus, Gary (2008). Kluge: The Haphazard Evolution of the Human Mind. Boston, MA: Houghton-Mifflin.

Martin-Albo, Jose, Nunez, Juan L., Navarro, Jose G. and Grijalvo, Fernando (2007). "The Rosenberg SelfEsteem scale: Translation and validation in university students", The Spanish Journal of Psychology. Vol.10: 458-467.

Mendelson, Beverley K., Mendelson, Morton J. and White, Donna R. (2001). "Body-esteem scale for adolescents and adults", Journal of Personality Assessment. Vol.76: 90-106.

Miller, Evonne and Halberstadt, Jamin (2005). "Media consumption, body image and thin ideals in New Zealand men and women", New Zealand Journal of Psychology. Vol.34: 189-195.

Morry, Marian M. and Staska, Sandra L. (2001). "Magazine exposure: Internalization, self-objectification, eating attitudes, and body satisfaction in male and female university students", Canadian Journal of Behavioral Science. Vol.33: 269-279.

"National Heart, Lung, and Blood Institute (NHLBI) (2012) Calculate your Body Mass Index." (2012). http://www. nhlbisupport.com/bmi/. Access Date: 12.03.2012. 
$\mathrm{Ng}$, Cheng Yee (2007) "Expert: One in 10 young girls are prone to eating disorders." The Star. 24.06.2007.

Ogden, Jane and Mundray, Kate (1996). "The effect of the media on body satisfaction: The role of gender and size", European Eating Disorders Review. Vol.4: 171-182.

Petrie, T.A., Rogers, R., and Diehl, N. (1996). "Development and validation of the revised Beliefs About Attractiveness Scale", Paper presented at the 104th Annual Convention of the American Psychological Association, Toronto, Ontorio, Canada.

Posavac, Steven S., and Posavac, Heidi D. (2002). "Predictors of women's concern with body weight: The roles of perceived self-media ideal discrepancies and self-esteem", Eating Disorders. Vol.10: 153-160.

Rosenberg, Morris (1965). Society and the Adolescent Self-image. Princeton, NJ: Princeton University Press.

Schooler, Deborah and Trinh, Sarah (2011). "Longitudinal associations between television viewing patterns and adolescent body satisfaction”, Body Image. Vol.8: 34-42.

Schwarz, Donna J., Phares, Vicky, Tanleff-Dunn, Stacey and Thompson, J. Kevin (1999). "Body image, psychological functioning, and parental feedback regarding physical appearance", International Journal of Eating Disorders. Vol.25: 339-343.

Sheldon, Pavica (2010). "Pressure to be perfect: Influences on college students' body esteem", Southern Communication Journal. Vol.75: 277-298.

Stice, Eric and Shaw, Heather E. (1994). "Adverse effects of the media portrayed thin-ideal on women and linkages to bulimic symptomatology”, Journal of Social and Clinical Psychology. Vol.13: 288 - 308.

Swami, Viren, Taylor, Rosanne and Carvalho, Christine (2011). "Body dissatisfaction assessed by the photographic figure rating, scale is associated with sociocultural, personality, and media influences", Scandinavian Journal of Psychology. Vol.52: 57-63.

Tan, Shiow Chin (2011) "Going into 2011." The Star. 02.01.2011.

Thogersen-Ntoumani, Cecilie, Ntoumani, Nikos, Cumming, Jennifer, Bartholomew, Kimberley J. and Pearce,

Gemma (2011). "Can self-esteem protect against the deleterious consequences of self-objectification for mood and body satisfaction in physically active female university students?" Journal of Sport and Exercise Psychology. Vol.33: 289-307.

Tucci, Sonia and Peters, Jennifer (2008). "Media influences on body satisfaction in female students", Psicotherma. Vol.20: 521-524.

Vartanian, Lesa Rea, Giant, Carrie and Passino, Rhonda (2001). "Ally McBeal vs. Arnold Schwarzengger: Comparing mass media, interpersonal feedback and gender with body thinness and muscularity", Social Behavior and Personality. Vol.29: 711-724.

Weaver, Angela D. and Byers, E. Sandra (2006). "The relationship among body image, body mass index, exercise, and sexual functioning in heterosexual women", Psychology of Women Quarterly. Vol.30: 333-339.

Zikmund, William G. (1997) Business Research Methods (5th ed.) Florida: The Dryden Press. 